EXPERIMENTAL STUDY

\title{
Rapid signal transduction in Sertoli cells
}

Fátima R M B Silva, Laura D Leite ${ }^{1}$ and Guillermo F Wassermann ${ }^{2}$

Departamento de Bioquímica, ${ }^{1}$ Departamento de Ciências Fisiológicas, Centro de Ciências Biológicas, UFSC,

Florianópolis-Santa Caterina and ${ }^{2}$ Departamento de Fisiologia, Instituto de Ciências Básicas da Saúde, UFRGS, Porto Alegre-Rio Grande do Sul, Brasil

(Correspondence should be addressed to F R M Barreto Silva, Departamento de Bioquímica, Centro de Ciências Biológicas, UFSC Campus Universitário, Bairro Trindade, Cx Postal 5069, CEP 88040-970-Florianópolis, Santa Catarina, Brasil; Email: mena@mbox1.ufsc.br)

\begin{abstract}
The importance of non-genomic signaling as a complementary route for cell regulation has recently become evident. This rapid mechanism is utilized not just by peptide hormones, but also by steroids and other lipid-related substances, resulting in amplification and fine-tuning of the signals. The Sertoli cell is the principal target for hormone action in the seminiferous tubules. The involvement of FSH, testosterone and tri-iodothyronine $\left(\mathrm{T}_{3}\right)$ in the spermatogenetic process is widely known. This paper discusses some rapid responses to $\mathrm{FSH}$, retinol, testosterone and $\mathrm{T}_{3}$ in the control of Sertoli cell function. Studies employing various methodologies and techniques are described and several hypotheses are considered in an attempt to explain the interactions of hormones with plasma membrane receptors. Recent knowledge about these new signaling mechanisms and cross-talk between them opens new fields of research on the communication and integration of the multiple hormonal signaling systems.
\end{abstract}

European Journal of Endocrinology 147 425-433

\section{Introduction}

Non-genomic signaling, which employs specific membrane receptors, second messengers and is typically exerted by peptide hormones and cytokines, has often been contrasted with genomic signaling, which requires alterations of gene transcription for generation of biologically meaningful signals. The classical genomic pathway lacks two properties when compared with fast, non-genomic responses: (a) speed (it takes at least $15 \mathrm{~min}$ to change the transcription level of a gene, translate the required protein and introduce post-translatory modifications) and (b) amplification and fine tuning of the signal (1).

A variety of evidence has accumulated related to the rapid responses to steroid substances such as estradiol, aldosterone, progesterone, testosterone, 1,25-dihyroxyvitamin $\mathrm{D}_{3}$ and also to retinol and tri-iodothyronine $\left(\mathrm{T}_{3}\right)$ (2). Recently, many authors have contributed to the understanding of the molecular processes underlying the rapid responses to these hormones in the control of spermatogenesis by Sertoli cells. In this review, we will emphasize the rapid non-genomic response, which may be viewed as a useful complementary pathway to genomic mechanisms, further increasing the diversity and improving the regulation of the effects of this family of hormones in Sertoli cells.
The testes have unique functions in the male body: the generation of gametes, as well as the production and controlled release of sex steroids. The structural compartmentalization into seminiferous tubules and interstitium determines the topographical division of their dual functions: spermatogenesis and steroidogenesis $(3,4)$.

The Sertoli cell comprises the main structural component of the seminiferous epithelium and has a cytoplasmic arrangement surrounding germinal cells, thus providing a controlled microenvironment and creating an immunologically protected space (4). In the mammalian testis, the Sertoli cell plays a key role in the initiation and maintenance of spermatogenesis (5). The structure of Sertoli cells and the specialized junctions between them and the neighboring germ cells create a sophisticated microenvironment providing all the nutrients and growth factors required for the full development of spermatogenetic cells (5).

In the rat, Sertoli cells proliferate during the fetal and early neonatal periods before assuming a terminally differentiated state $(6,7)$. Both the rate and the duration of the proliferative phase determine the ultimate number of Sertoli cells in the adult testis. It has been demonstrated that each Sertoli cell is capable of supporting a limited number of germ cells through to maturity; hence, Sertoli cell number determines the maximum spermatogenic potential of the testis $(8,9)$. 
The Sertoli cell has been shown to be a target site for the action of several hormones, such as folliclestimulating hormone (FSH) and testosterone, both with important roles in controlling spermatogenesis, although the participation of other hormones such as $\mathrm{T}_{3}$, retinol and 1 $\alpha, 25$-dihyroxyvitamin $\mathrm{D}_{3}\left(1 \alpha, 25(\mathrm{OH})_{2} \mathrm{D}_{3}\right)$ in the spermatogenetic process is of relevant significance. These hormones also regulate aspects of metabolic control, testicular size and weight, as well as changes in testicular morphology through their classical nuclear mechanism of action $(10-13)$.

\section{Testosterone}

Androgens are the principal steroids synthesized by the Leydig cells of the testis and testosterone is by far the most important androgen because of its potency. A major and undisputed function of androgens is the regulation of gene expression in many different target cells. The testis also secretes estrogens, which are synthesized by both Leydig cells and Sertoli cells (5).

Spermatogenesis depends on the concomitant action of the gonadotropin FSH and testosterone in the Sertoli cells (10). After being synthesized by Leydig cells, testosterone is delivered to Sertoli cells where it binds to androgen-binding protein (ABP), thus keeping a high concentration of testosterone in the lumen of the tubules. This is necessary for the normal maturation of developing spermatozoa (14) and also promotes its nuclear effect through a sequence of events similar to those initiated by other steroid hormones. The study of membrane-initiated actions of steroid compounds in different cell systems has become an expanding field of research in recent years (15).

A steroid-modulated import of substances such as ions, sugars or amino acids across the cell membrane, mediated by signal cascades in the cytoplasm, involving the activation of protein kinases, opening of ion channels or stimulated release of second messengers, has been postulated as a preparative step to support subsequent protein synthesis controlled by steroid hormones that bind to nuclear receptors $(16,17)$. Evidence points to intracellular second messengers as mediators of steroid-induced transcription by intracellular cross-talk (15).

Rapid effects of androgens have been described in various tissues such as brain, blood, heart, bone, ovary, prostate and testis (15). Some of the nongenomic actions of steroids involve rapid ion movements across the cell membrane (15). Many studies have revealed the modulation by steroids of calcium channel activity in the membrane of several different cell systems $(18-20)$. Also, it has been shown that steroid hormones modulate other ion channels such as $\mathrm{K}^{+}, \mathrm{Na}^{+}$and $\mathrm{Cl}^{-}$channels $(18,21-23)$.
Three main research groups have studied the non-genomic actions of testosterone on Sertoli cells. Rommerts, in 1992 (24), reported that the levels of testosterone required to maintain spermatogenesis are much higher than the saturation level of the highaffinity androgen nuclear receptor, and it is difficult to imagine how an oversaturated receptor (99\%) can respond to increased levels of steroids. To explain these observations, an alternative sensing system, different from the classical receptor, was postulated (24).

In order to investigate this alternative sensing system, this group took into consideration the finding relating to a specific class of steroids (neurosteroids) that do not possess exclusively genomic activity and can rapidly influence functional properties of neurons in the brain, thereby affecting sleep patterns, the reaction to stress, memory function and so on (25).

The existence of an alternative cell surface receptor system for androgens in immature (prepubertal) rat Sertoli cells has been postulated from calcium flux measurements. Lyng et al. (26) showed that Sertoli cells from cultured tubular fragments from 20-day-old rats responded to exogenous testosterone, testosterone bound to albumin, dihydrotestosterone and R1881, a synthetic androgen, with a transient fast (20-30s) increase in intracellular calcium levels. This rapid increase in calcium was inhibited by a voltagedependent calcium channel (VDCC) blocker, verapamil. The same research group also showed that the non-genomic effects of testosterone improved the efficiency of gap junctions between Sertoli cells. These data indicate that androgens can exert rapid nongenomic effects on calcium transients at physiological concentrations but also far above the saturation level of the nuclear receptor and with a steroid specificity that differs from that of the nuclear receptor.

Gorczynska \& Handelsman (27), on the other hand, showed that Sertoli cell aggregates isolated from immature rats responded to higher concentrations $(0.3-3 \mu \mathrm{M})$ of testosterone, dihydrotestosterone and testosterone covalently bound to albumin with an increase in calcium levels within 20 to 40 s. Estradiol had a minor effect and progesterone had no effect. Furthermore, these researchers found that the effect could be inhibited in the following ways: (a) preincubating the cells with hydroxyflutamide (nonsteroidal antiandrogen) or finasteride ( $5 \alpha$-reductase inhibitor), (b) removing extracellular calcium or (c) pharmacological blockade of membrane calcium channels. This study suggests that the testosteroneinduced rise in Sertoli cell cytosolic calcium involves $5 \alpha$-reduction, an androgen-binding element similar to that for classical androgen receptors, and activation of extracellular calcium currents into the cell pointing to an acute, non-genomic effect of testosterone in Sertoli cell regulation, in addition to the classical, slower, genomic response. 
In order to investigate a possible synergistic action between rapid responses to FSH and testosterone, the action of testosterone on the membrane potential of Sertoli cells was studied. Leite et al. (28) demonstrated that testosterone promotes an immediate $(<1 \mathrm{~s})$ and transitory dose-dependent membrane depolarization in Sertoli cell-enriched seminiferous tubules from prepubertal and pubertal rats. Testosterone also had (in 30 s) a stimulatory action on ${ }^{45} \mathrm{Ca}^{2+}$ uptake in isolated Sertoli cells from testes at various stages of maturation (20-60 days of age). The hormone did not have any action on amino acid transport at any of the maturation stages tested.

Testosterone's depolarizing effect points to a nonrandom response and to a high specificity of the hormone for its putative plasma membrane receptor on Sertoli cells, suggesting a rapid, non-genomic effect. This effect probably involves the closing of ATP-dependent $\mathrm{K}^{+}$channels $\left(\mathrm{K}^{+}\right.$-ATP $)$, since the $\mathrm{K}^{+}$-ATP channel agonist diazoxide nullified testosterone's action. These results were observed with concentrations of testosterone between 0.20 and $0.30 \mu \mathrm{M}$, close to that which is normally found in rat testicular fluid (29), suggesting that the depolarizing effect caused by testosterone inhibition of the $\mathrm{K}^{+}$-ATP channel induces calcium uptake through voltage-dependent calcium channels of the L-type (E I C F von Ledebur, J P Almeida, E S Loss \& G F Wassermann, unpublished observations), as depicted in Fig. 1. A similar effect was postulated for the action of glibenclamide in Sertoli cells and $\beta$-cells of the pancreatic islet $(30,31)$.

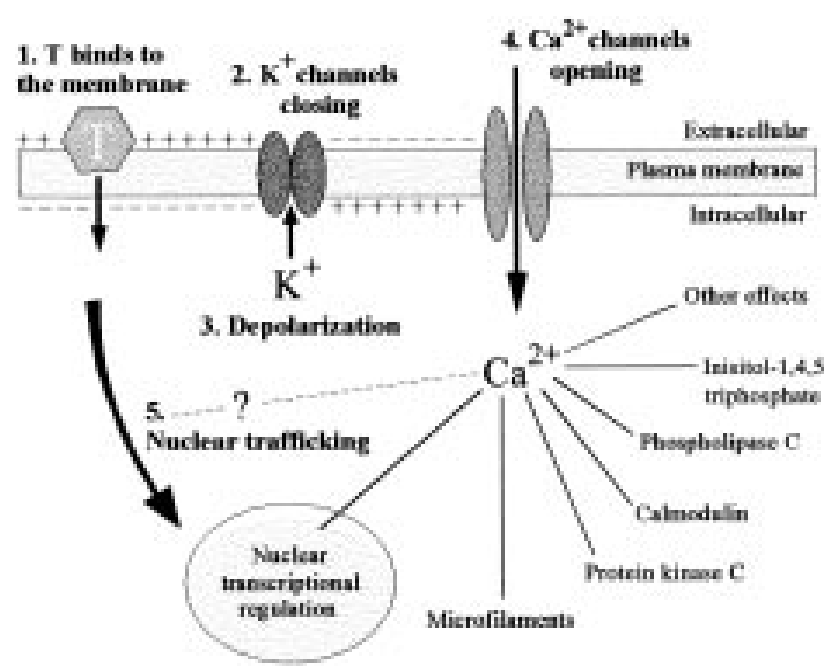

Figure 1 Schematic representation of the possible mechanisms of action of testosterone on the Sertoli cell membrane. Testosterone interaction with the Sertoli cell membrane (1) closes the $\mathrm{K}^{+}$-ATP channel (2) depolarizing the cell (3) allowing the opening of the VDCC (4) and an increase in $\mathrm{Ca}^{2+}$ uptake. The local $\mathrm{Ca}^{2+}$ transient may produce some of the effects commonly associated with this ion, for example, speeding the cytoplasmic trafficking of non-polar substances $(T)$, modulating transcription, etc.

\section{Follicle-stimulating hormone}

FSH is a glycoprotein produced by the anterior pituitary gland that acts on the testis by regulating gametogenesis and steroidogenesis. FSH promotes spermatogenic output by increasing the number of Sertoli cells $(32,33)$. There is well-established evidence that FSH regulates Sertoli cell function from early embryogenic development onwards (7) and exerts pleiotropic effects through a variety of signaling pathways (34-36).

The Sertoli cell is the major FSH-responsive cell within the testis. There seem to be at least two different, possibly unrelated, pathways through which the binding of FSH to its receptors can initiate signal transduction: (a) binding to high-affinity receptors activating adenyl cyclase, followed by an increase in intracellular cAMP, and activation of cAMP-dependent protein kinase, resulting in stimulation of the phosphorylation of several proteins $(37,38)$ and (b) through the opening or closing of ion channels in the plasma membrane. In this latter case, FSH would act by altering the membrane potential in the Sertoli cell, thereby stimulating an increase in intracellular calcium levels and activating many cellular functions (39-43).

The effects of FSH on Sertoli cells have been widely studied, but whether both pathways are activated by a single $G$ protein-coupled receptor with the seventransmembrane structure has remained unclear. Participation of $\mathrm{G}$ proteins in the regulation of voltagedependent $\mathrm{Ca}^{2+}$ channels, ATP-dependent $\mathrm{K}^{+}$channels, ligand-gated $\mathrm{K}^{+}$channels and muscarinic acetylcholine receptors has been demonstrated (44).

Much evidence points to a rapid response to FSH involving the second mechanism (b), mentioned above, of signal transduction. Joffre \& Roche (45), using Sertoli cells from immature rats in monolayer culture, observed a hyperpolarization of the cell membrane induced by FSH and this effect was related to the activation of a $\mathrm{K}^{+}$current blocked by quinidine. Furthermore, this hyperpolarizing action was modified by treatments that either increased intracellular calcium or decreased extracellular calcium $(45,46)$.

Subsequently, these investigators have also studied the role of calcium in FSH stimulation. In a series of more recent experiments, using the whole-cell configuration of the patch-clamp technique, the presence of voltage-dependent T-type calcium channels was demonstrated in the membrane of immature Sertoli cells in primary culture (47).

Later, using the single-cell microfluorometry technique with the calcium probe indo-1, this same group studied the intracellular calcium concentration in individual cultured Sertoli cells when these cells were exposed to ATP, cAMP and FSH. Lalevée \& Joffre (48) concluded that the role of FSH in $\mathrm{Ca}^{2+}$ movements in immature Sertoli cells is dependent on previous intracellular $\mathrm{Ca}^{2+}$ levels. For instance, when the calcium level is high, FSH induces a progressive decrease 
in intracellular calcium concentrations by redistribution of calcium from the cytosol in a bound nonexchangeable pool. Furthermore, $\mathrm{Ca}^{2+}$ movements induced by FSH may be modulated by myoid cells and by germ cells (48).

Another research group has demonstrated FSHstimulated uptake of ${ }^{45} \mathrm{Ca}^{2+}$ in two different systems: (a) proteoliposomes containing incorporated FSH receptor solubilized from bovine calf testicular membranes and (b) cultured Sertoli cells from immature rats (39). In both models, calcium entry into Sertoli cells appears to be a receptor-mediated process involving voltage-independent and voltageactivated calcium channels.

The introduction of the non-metabolizable amino acid transport model by Christensen et al. (49) enabled studies on the mechanism of action of hormones and vitamins, thereby distinguishing protein synthesis from alternative amino acid uptake pathways. Using this approach, it has been demonstrated that FSH can modulate Sertoli cell function in several ways (50, 51). In vivo, FSH treatment stimulated $\left[\alpha^{-14} \mathrm{C}\right]$ aminoisobutyric acid transport into testes. This effect was age-related (between 5 and 22 days) and specific to FSH $(50,52)$.

It is well known that FSH stimulates adenyl cyclase, cAMP and cyclic adenosine monophosphate-dependent protein kinase A (PKA) (37). However, the hormone also stimulates $\mathrm{Na}^{+}$-amino acid co-transport through system 'A' $(52,53)$. Additionally, it was reported that cholera toxin, dibutyryl cAMP or cAMP are unable to reproduce the effect of FSH on the amino acid transport (52, 54). Likewise, FSH stimulates ${ }^{45} \mathrm{Ca}^{2+}$ uptake through a mechanism that does not require activation of cholera toxin- or pertussis toxin-sensitive guanine nucleotide-binding protein or adenyl cyclase (55).

The stimulatory action of FSH on amino acid transport is completely nullified by nickel, $\mathrm{Co}^{2+}$ and the blocker of L-type VDCC verapamil (36), indicating the critical role of $\mathrm{Ca}^{2+}$ in this FSH effect. Electrophysiological studies showed that FSH binds to its receptor and produces a dose-dependent biphasic effect characterized by an immediate hyperpolarization followed by a depolarization. The depolarizing effect of FSH was prolonged and potentiated in the presence of $\alpha$-methylaminoisobutyric acid (MeAIB) and nullified by the blocker of L-type VDCC, verapamil $(36,41)$.

Davare et al. (56) reported that the $\beta_{2}$-adrenergic receptor was found to be directly associated with one of its ultimate effectors, the class C L-type calcium channel $\mathrm{Ca}_{\mathrm{v}}$ 1.2. This complex also contained a $\mathrm{G}$ protein, adenyl cyclase, cAMP, PKA and protein phosphatase. Electrophysiological recordings from hippocampal neurons demonstrated highly localized signal transduction from the receptor to the channel.

Similarly, FSH, as described above for adrenergic agents, can open the L-type VDCC through a direct interaction between the receptor and the channel.
This action would stimulate ${ }^{45} \mathrm{Ca}^{2+}$ uptake, cellular depolarization and amino acid co-transport (see Fig. 2).

Recently, analysis of the kinetics of $\left[1-{ }^{14} \mathrm{C}\right] \mathrm{MeAIB}$ uptake in Sertoli cells revealed that the stimulatory action of FSH on $\left[1-{ }^{14} \mathrm{C}\right] \mathrm{MeAIB}$ transport was caused by a rise in $V_{\max }$, indicating an increase in the activity of functional transporters. The fact that the FSH effect was evident after $120 \mathrm{~s}$, and was almost maximal after around $15 \mathrm{~min}$ suggests that FSH can induce the activation of pre-existing silent transporters already incorporated into the cell membrane (51). The $V_{\max }$ increase in amino acid transport caused by FSH
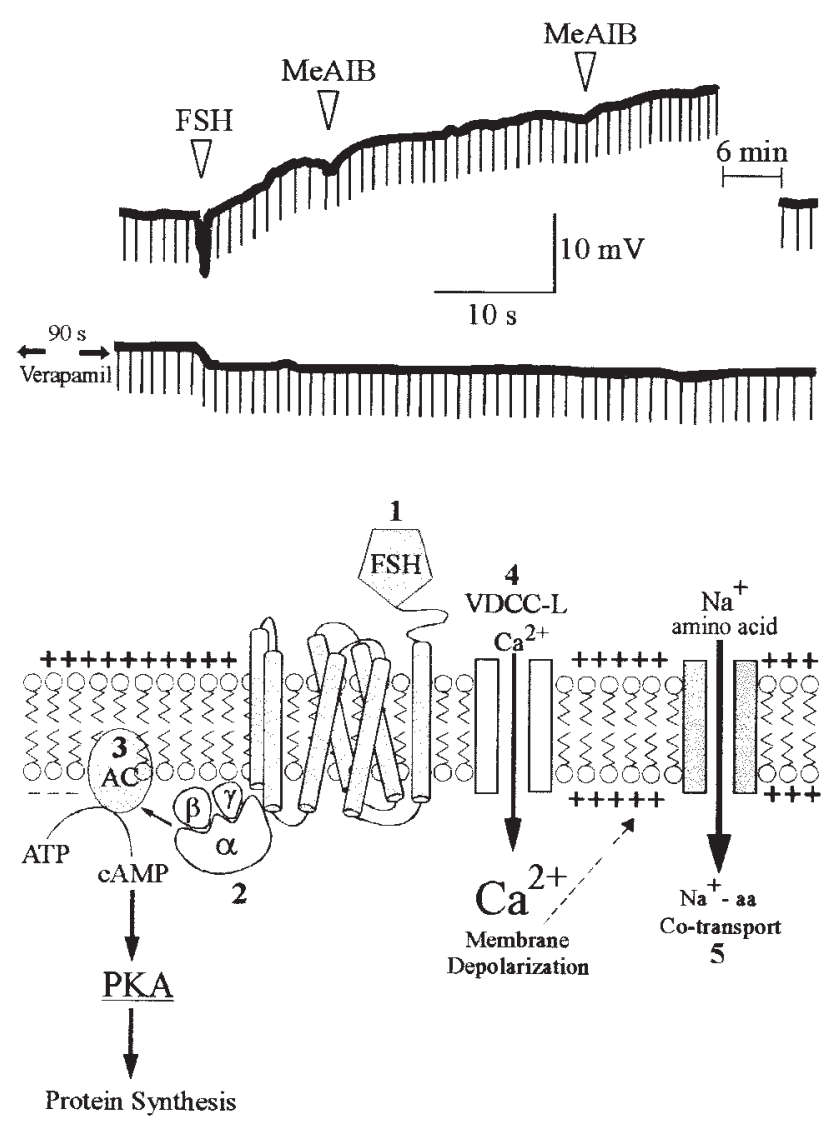

Figure 2 Schematic representation of the possible mechanisms of action of FSH on the Sertoli cell membrane. Top: Electrophysiological effects of FSH on the Sertoli cell membrane. Bottom: The G protein-coupled FSH receptor (GPCR) (1) may form part of a multiprotein signaling complex in a membrane microdomain that contains a heterotrimeric $\mathrm{G}$ protein (2), an adenylate cyclase (AC), PKA (3) and an L-type VDCC closely associated with the receptor (4). The calcium channel activation leads to the opening of a sodium channel coupled to the amino acid (aa) co-transport system (5). The interaction of FSH with its GPCR produces stimulation of adenylate cyclase, activates PKA, catalyses the phosphorylation of proteins and the modulation of transcription through cAMP response protein. Concomitantly, a specific signal transduced from the receptor to the L-type VDCC increases the channel activity. The rise in local $\mathrm{Ca}^{2+}$ concentration produces a depolarization (prevented by verapamil) that triggers $\mathrm{Na}^{+}$-amino acid co-transport through the activation of pre-existing carriers (5) increasing the membrane depolarization. 
reinforces the involvement of pre-existing transporter proteins as a consequence of the rapid biphasic effect of FSH on the membrane potential of Sertoli cells.

\section{Retinol}

Retinol (vitamin A alcohol) is the precursor of biologically active retinoids such as retinaldehyde and retinoic acid. The retinoid nuclear receptors are functionally and structurally related to the steroid/thyroid hormone receptors and, overall, the physiological actions of vitamin A could also be considered in the context of a retinoid hormonal system (57).

Vitamin A, in the form of retinol, is essential for maintenance of spermatogenesis and testicular function (12). Cellular retinoid-binding proteins have been localized in Sertoli cells and germinal cells (58, 59). Retinol can act on Sertoli cell metabolism, stimulating the synthesis and secretion of several proteins and glycoproteins $(60,61)$ as well as modulating ornithine decarboxylase activity and iron metabolism $(62,63)$.

The physiological effect of retinoids depends on numerous factors: metabolic pathways, nuclear receptors, cytosolic retinoid-binding proteins, nonprotein-bound retinoids, regulation of gene transcription and the activity of other signal transduction pathways involving protein kinases and changes in membrane structure/micro-viscosity $(57,60)$.

Evidence of a rapid response to retinol in Sertoli cells was demonstrated by Wassermann's group in 1993 (64). It was shown, in whole gonads and in Sertoli cell-enriched cultures from immature rat testes, that retinol stimulates $\left[1-{ }^{14} \mathrm{C}\right] \mathrm{MeAIB}$ uptake. This effect of retinol occurred by the 'A' transport system and was inhibited by cobalt and nickel, suggesting the involvement of VDCC (64).

$A$ rapid effect of retinol on the plasma membrane was also demonstrated through studies involving ${ }^{45} \mathrm{Ca}^{2+}$ uptake in isolated Sertoli cells from immature rat testes. An acute (20s), stimulatory action of retinol on calcium uptake was detected involving, at least in part, verapamil-sensitive VDCC (65). Later, the action of retinol at the cell surface was reinforced by experiments that demonstrated that this rapid stimulatory effect of retinol on amino acid uptake is independent of protein synthesis, being processed through a peripheral mechanism, probably located in or near the plasma membrane (66).

Electrophysiological studies showed that retinol caused an immediate $(<1 \mathrm{~s})$ oscillatory response in the membrane potential and induced a reduction in membrane resistance in Sertoli cells (67). Therefore, these results indicated that, besides the classical nuclear effects, retinol stimulates a peripheral mechanism directly involving the plasma membrane. These changes in Sertoli cell membrane function produced by retinol are probably associated with the stimulatory action of this hormone on amino acid accumulation and on calcium uptake $(65,67)$.

Retinol and FSH act on the testis stimulating nuclear events (ABP, plasminogen activator and transferrin synthesis) as well as non-genomic events (amino acid transport, calcium influx and changes in Sertoli cell membrane potential). Ultimately, they share common elements of a plasma membrane rapid stimulatory effect mediated by amino acid transport mechanisms. Both substances act on the 'A' transport system through VDCC, are independent of de novo protein synthesis and their effects are non-additive $(36,64,66)$.

Due to the low solubility of retinoids, retinol-binding proteins facilitate the uptake of retinol by Sertoli cells (60). But whether retinol, retinoic acid and/or retinol ester are transported by germinal cells remains to be investigated. A possible explanation for retinol's effect is related to its lipophylic nature. Retinol can dissolve in and move through the lipid bilayer of membranes, interacting with the plasma membrane and triggering signal transduction mechanisms by modulating protein kinase $\mathrm{C}$, kinase $\mathrm{A}$ or by altering the membrane permeability to water, ions, glucose and amino acids $(60,64,67-70)$. However, further studies need to be performed since the mechanism underling the rapid response to retinol in Sertoli cells is still unclear.

\section{Tri-iodo-L-thyronine}

Thyroid hormones influence steroidogenesis as well as spermatogenesis. $\mathrm{T}_{3}$ acts directly on the initiation of spermatogenesis independent of testosterone, and possibly with no dependence on FSH availability (71, 72).

The biochemical effects of $\mathrm{T}_{3}$ in vivo as well as in vitro demonstrated that the Sertoli cell is the main testicular target for the thyroid hormone, and there is a remarkable temporal frame for its action coincident with the prepubertal period $(11,73,74)$. There is increasing evidence that $\mathrm{T}_{3}$ and thyroxine influence the duration of proliferation of Sertoli cells and accelerate tubular lumen formation in the rat testis $(11,75)$.

Nuclear thyroid hormone receptors (TR) are encoded by two closely related proto-oncogenes, c-erbA $\alpha$ and c-erbA $\beta$. The splicing of gene primary transcripts can lead to at least four distinct mRNA species generating separate TR isoforms: $\mathrm{TR} \alpha_{1}, \mathrm{TR} \alpha_{2}, \mathrm{TR} \beta_{1}$ and $\mathrm{TR} \beta_{2}$ (76).

The relative expression and distribution of the TR genes vary from tissue to tissue and during different stages of development (77). Sertoli cell function has received much attention since the finding of functional $\mathrm{T}_{3}$ receptor expression in prepubertal testes. An ontogenetic pattern of $\mathrm{TR} \alpha_{1}$ and $\mathrm{TR} \alpha_{2}$ expression and of $\beta$ mRNA receptor has been demonstrated in Sertoli cells $(78,79)$. This allows the use of the testis as a naturally occurring model for studying the role of TR 
in the modulation of gene expression and cellular function in vivo $(73,79)$.

Thyroid hormones stimulate glucose transport, increase the production of $\gamma$-glutamyl transpeptidase, ABP and insulin-like growth factor-I, inhibit aromatase activity and affect testosterone metabolism in Sertoli cells (73). Concerning the thyroid hormone mechanism of action, the following hypotheses have emerged: (a) nuclear effect as the sole primary site of action which has, as a consequence, the modulation of gene expression and protein synthesis $(80,81)$ and (b) several primary action sites within the target cell, including the nucleus, mitochondria and the plasma membrane $(74,80,82,83)$. A wealth of evidence for the action of thyroid hormones at the level of the nucleus and mitochondrion is very well described elsewhere $(82-85)$ and will not be discussed here. In this review, we confine ourselves to plasma membrane effects of the hormones and raise some hypotheses for the mechanism of action thereupon in Sertoli cells.

A wide body of data shows that thyroid hormone effects are prompt in onset, independent of protein synthesis and/or alter ionic fluxes in various tissues (86-88). As was shown for FSH, testosterone and retinol, electrophysiological and amino acid accumulation models have also contributed to the clarification of the rapid response mechanism of action of $\mathrm{T}_{3}$ on the plasma membrane of Sertoli cells. $\mathrm{T}_{3}$ significantly stimulated amino acid accumulation in testes from immature rats confirming the age-dependent action of the hormone. Also, electrophysiological studies demonstrated that $\mathrm{T}_{3}$ produced an immediate hyperpolarization of the Sertoli cell membrane. These two effects could be related to one another.

Wassermann et al. (43) and Lalevée et al. (47) have suggested the presence of voltage-dependent T-type calcium channels in the membrane of immature Sertoli cells. Furthermore, using the patch-clamp technique, in the whole-cell configuration, $\mathrm{Ca}^{2+}$-dependent $\mathrm{Cl}^{-}$ currents have been characterized in cultured Sertoli cells from immature rat testis (48). Both findings suggest that calcium is involved in the hyperpolarizing effect of $\mathrm{T}_{3}$.

Silva et al. (74) have proposed a modulatory mechanism involving $\mathrm{Ca}^{2+}$-dependent $\mathrm{Cl}^{-}$currents or $\mathrm{Ca}^{2+}$ dependent $\mathrm{K}^{+}$currents, suggesting that calcium influx can be influenced by both ions, triggering signaling pathways that modulate amino acid accumulation.

\section{Other steroid hormones}

\section{1 $\alpha, 25$-dihydroxyvitamin $\mathrm{D}_{3}$}

$1 \alpha, 25(\mathrm{OH})_{2} \mathrm{D}_{3}$, the major hormonally active product of the vitamin D endocrine system, exhibits rapid and genomic responses (89). The genomic effects are dependent upon the interaction of $1 \alpha, 25(\mathrm{OH})_{2} \mathrm{D}_{3}$ with a cytosolic/nuclear receptor protein followed by the action of the steroid receptor complex in the nucleus, activating or suppressing gene expression (90, 91). The rapid responses triggered by $1 \alpha, 25(\mathrm{OH})_{2} \mathrm{D}_{3}$ have been postulated as a consequence of interaction of the ligand with a putative cell membrane receptor for $1 \alpha, 25(\mathrm{OH})_{2} \mathrm{D}_{3}$. This binding could then activate a variety of signal transduction systems such as $\mathrm{G}$ proteins, resulting in the activation of protein kinase $\mathrm{C}$, phospholipase $\mathrm{C}$, adenyl cyclase, intracellular $\mathrm{Ca}^{2+}$ redistribution, opening of $\mathrm{Ca}^{2+}$ or $\mathrm{Cl}^{-}$channels and the activation of both Raf and Mitogen-activated protein kinase pathways $(92,93)$.

Vitamin D has an important role in reproductive function, since a reduction in fertility was observed in vitamin D-deficient male rats (13). However, it is interesting to note that although $1 \alpha, 25(\mathrm{OH})_{2} \mathrm{D}_{3}$ nuclear receptors were detectable in Sertoli cells from different species, the direct effect of $1 \alpha, 25(\mathrm{OH})_{2} \mathrm{D}_{3}$ on the Sertoli cell is not clear (94-96).

Thus, Sertoli cells seem to be a potential target for the following $1,25(\mathrm{OH})_{2} \mathrm{D}_{3}$ studies: (a) $1,25(\mathrm{OH})_{2} \mathrm{D}_{3}$ receptor ontogeny, (b) subcellular distribution of $1,25(\mathrm{OH})_{2} \mathrm{D}_{3}$ receptors, (c) direct plasma membrane effects of $1,25(\mathrm{OH})_{2} \mathrm{D}_{3}$ and (d) specificity of action and physiological relevance of $1,25(\mathrm{OH})_{2} \mathrm{D}_{3}$ in intracellular calcium homeostasis and its possible regulation of ionic metabolism.

Specific non-genomic responses to estradiol, aldosterone, progesterone and corticosteroids have been intensively studied in a variety of tissues (15). In the testis, they have an influence on spermatogenesis and/or steroidogenesis $(15,97,98)$. However, according to the literature, there are as yet no studies addressing rapid response mechanisms in Sertoli cells to these hormones.

\section{Conclusion}

In order to clarify the events related to steroidogenesis and spermatogenesis, studies have been performed on the mechanisms that mediate genomic and nongenomic effects of hormones on Sertoli cells. These steroid actions may occur by two mechanisms: (a) interaction of steroids with specific receptors (classical nuclear receptor and non-classical steroid receptor) and (b) interaction of steroids with non-specific proteins and/or membrane lipids (no receptor involved) (15).

Although the classical molecular mechanisms of the action of FSH, testosterone, $\mathrm{T}_{3}$ and retinol on Sertoli cells are widely known, rapid responses to these hormones also seem to contribute to the initiation and maintenance of normal spermatogenesis. Although FSH and testosterone may share some biochemical pathways having calcium as a common intracellular effector, each hormone seems to display its own molecular mechanism. 
FSH as well as testosterone stimulates $\mathrm{Ca}^{2+}$ uptake in the Sertoli cells. However, these $\mathrm{Ca}^{2+}$ increments have different consequences: the increase in $\mathrm{Ca}^{2+}$ produced by FSH is closely related to the stimulation of amino acid transport, whereas the increment produced by testosterone is not. This discrepancy is not surprising, since the different spatial distribution of $\mathrm{Ca}^{2+}$ transients can provide a way to achieve specificity or, alternatively, cross-talk among second messengers can induce different and specific responses.

Studies on rapid responses to steroids and related substances could aid in the development of new drugs to treat infertility problems and could contribute to the advancement of male contraceptive research. According to recent data, spermatogonial transplantation (syngeneic and xenogeneic) has been a technological breakthrough in the study of Sertoligerm cell interaction (99). Clearly, this achievement would have applications in the basic sciences, human medicine, and in domestic and wild animal reproduction.

\section{Acknowledgements}

This work was supported by grants from FunpesquisaUniversidade Federal de Santa Catarina-UFSC, Conselho Nacional de Desenvolvimento Científico e Tecnológico-CNPq, Fundação de Amparo à Pesquisa do Rio Grande do Sul (FAPERGS), Financiadora de Estudos e Pesquisa (FINEP) and CAPES/PG-FAR-UFSC. The authors express their appreciation to $\mathrm{Dr} G \mathrm{P}$ Cuttle for assistance with the English correction of the manuscript and to L F Sella for the schematic drawings.

This work is dedicated to the memory of Dr L D Russel, a fine researcher in this field.

\section{References}

1 Gniadecki R. Nongenomic signaling by vitamin D. Biochemical Pharmacology 199856 1273-1277.

2 Wehling M. Specific, nongenomic actions of steroid hormones. Annual Review of Physiology 199759 365-393.

3 Dym M \& Fawcett DW. The blood-testis barrier in the rat and the physiological compartmentation of the seminiferous epithelium. Biology of Reproduction 19703 308-326.

4 Schlatt S, Meinhardt A \& Nieschlag E. Paracrine regulation of cellular interactions in the testis: factors in search of a function. European Journal of Endocrinology 1997137 107-117.

5 Carreau S, Foucault P \& Drosdoesky MA. La cellule de Sertoli: aspects fonctionnels comparés chez le rat, le porc et l'homme. Annals d'Endocrinologie 199455 203-220.

6 Orth J. Proliferation of Sertoli cells in fetal and postnatal rats: a quantitative autoradiographic study. Anatomical Record 1982 203 485-492.

7 Sasaki M, Yamamoto M, Arishima K \& Eguchi Y. Effect of folliclestimulating hormone on Sertoli cell division in cultures of fetal rat testes. Biology of the Neonate $2000 \mathbf{7 8} 48-52$.

8 Jones L \& Berndtson W. A quantitative study of Sertoli cell and germ cell populations as related to sexual development and ageing in the stallion. Biology of Reproduction $1986 \quad 35$ $138-148$.

9 Simorangkir D, Wreford N \& De Kretser D. Impaired germ cell development in testes of immature rats with neonatal hypothyroidism. Journal of Andrology 199718 186-193.

10 Arslan M, Weinbauer GF, Schlatt S, Shahab M \& Nieschlag E. FSH and testosterone, alone or in combination, initiate testicular growth and increase the number of spermatogonia and Sertoli cells in a juvenile non-human primate (Macaca mulatta). Journal of Endocrinology 1992136 235-243.

11 Van Haaster LH, De Jong FH, Docter R \& De Rooij DG. High neonatal triiodothyronine levels reduce the period of Sertoli cell proliferation and accelerate tubular lumen formation in the rat testis, and increase serum inhibin levels. Endocrinology 1993 $133755-760$.

12 Huang HFS, Dyrenfurth I \& Hembree WC. Endocrine changes associated with germ cell loss during vitamin A-induced recovery of spermatogenesis. Endocrinology 1983112 1163-1171.

13 Kwiecinski GG, Petrie GI \& De Luca HF. Vitamin D is necessary for reproductive functions of the male rat. Journal of Nutrition 1989 $119741-744$.

14 Ross MH, Romrell LJ \& Kaye GI. Male reproductive system. In Histology: A Text and Atlas, edn 3, ch 21, pp 636-676. Baltimore: Williams \& Wilkins, 1995.

15 Falkenstein E, Tillmann HC, Christ M, Feuring M \& Wehling M. Multiple actions of steroid hormones - focus on rapid, nongenomic effects. Pharmacological Reviews 200052 513-555.

16 Koening A, Goldstone A \& Lu CY. Testosterone induces a rapid stimulation of endocytosis, amino acid and hexose transport in mouse kidney cortex. Biochemical and Biophysical Research Communications 1982106 346-352.

17 Watson CS \& Gametchu B. Membrane-initiated steroid actions and the proteins that mediate them. Proceedings of the Society for Experimental Biology and Medicine 1999 220 9-19.

18 Zanello LP \& Norman AW. Stimulation by 1alpha, $25(\mathrm{OH})_{2-}$ vitamin $\mathrm{D}_{3}$ of whole cell chloride currents in osteoblastic ROS $17 / 2.8$ cells. A structure-function study. Journal of Biological Chemistry 1997272 22617-22622.

19 Ruehlmann DO, Steinert JR, Valverde MA, Jacob R \& Mann GE. Environmental estrogenic pollutants induce acute vascular relaxation by inhibiting L-type $\mathrm{Ca}^{2+}$ channels in smooth muscle cells. FASEB Journal $1998 \mathbf{1 2} 613-619$.

20 Loechner KJ, Knox RJ, McLaughlin JT \& Dunlap K. Dexamethasone-mediated inhibition of calcium transients and ACTH release in a pituitary cell line (AtT-20). Steroids 199964 404-412.

21 Barann M, Göthert M, Brüss M \& Bönisch H. Inhibition by steroids of $\left[{ }^{14} \mathrm{C}\right]$-guanidinium flux through the voltage-gated sodium channel and the cation channel of the $5-\mathrm{HT}_{3}$ receptor of NIE-115 neuroblastoma cells. Naunyn-Schmiedeberg's Archives of Pharmacology $1999360234-241$.

22 Valverde MA, Rojas P, Amigo J, Cosmelli D, Orio P, Bahamonde MI et al. Acute activation of maxi-K channels (hslo) by estradiol binding to the $\beta$ subunit. Science 1999285 1929-1931.

23 Rabe A \& Fromter E. Micromolar concentrations of steroids and of aldosterone antagonists inhibit the outwardly rectifying chloride channel with different kinetics. Pflügers Archives 2000439 $559-566$.

24 Rommerts FF. Cell surface actions of steroids: a complementary mechanism for regulation of spermatogenesis? In Spermatogenesis, Fertilization, Contraception. Molecular, Cellular and Endocrine Events in Male Reproduction, Schering Foundation Workshop 4, pp 1-19. Eds E Nieschlag \& UF Habenicht. Berlin: SpringerVerlag, 1992.

25 Baulieu EE. Neurosteroids: a new function in the brain. Biology of the Cell $1991713-10$.

26 Lyng FM, Jones GR \& Rommerts FF. Rapid androgen actions on calcium signaling in rat Sertoli cells and two human prostatic cell lines: similar biphasic responses between 1 picomolar and 100 nanomolar concentrations. Biology of Reproduction 2000 $63736-747$. 
27 Gorczynska E \& Handelsman DJ. Androgens rapidly increase the cytosolic calcium concentration in Sertoli cells. Endocrinology $19951362052-2059$.

28 Leite L, Luchi R, von Ledebur EICF, Loss ES \& Wassermann GF. Testosterone induces immediate membrane depolarization and stimulates ${ }^{45} \mathrm{Ca}^{2+}$ uptake in Sertoli cells from rats of different maturation stages. Medical Science Research 199927 25-58.

29 Jarrow JP, Chen H, Rosner W, Trentacoste S \& Zirkin BR. Assessment of the androgen environment within the human testis: minimally invasive method to obtain intratesticular fluid. Journal of Andrology 200122 640-645.

30 Miranda MJ, Liedke PER, Leite L, Loss ES \& Wassermann GF. Glibenclamide changes membrane potential and stimulates ${ }^{45} \mathrm{Ca}^{2+}$ uptake and amino acid accumulation in Sertoli cells of immature rats. Medical Science Research 199826 703-706.

31 Boyd AE III. Sulfonylurea receptors, ion channels, and fruit flies. Diabetes $198837847-850$.

32 Meachem S, McLachlan R, De Kretser D, Robertson D \& Wreford N. Neonatal exposure of rats to recombinant follicle stimulating hormone increases adult Sertoli and spermatogenic cell numbers. Biology of Reproduction 199654 36-44.

33 Griswold MD. The central role of Sertoli cells in spermatogenesis. Seminars in Cell and Developmental Biology $19989411-416$.

34 Sharma OP, Flores JA, Leong DA \& Veldhuis JD. Cellular basis for follicle-stimulating hormone-stimulated calcium signaling in single rat Sertoli cells: possible dissociation from effects of adenosine 3',5'-monophosphate. Endocrinology $1994 \mathbf{1 3 4}$ 1915-1923.

35 Troispoux C, Reiter E, Combarnous Y \& Guillou F. Beta-2 adrenergic receptors mediate cAMP, tissue-type plasminogen activator and transferrin production in rat Sertoli cells. Molecular and Cellular Endocrinology 1998142 75-86.

36 Wassermann GF, Monti Bloch L, Grillo ML, Silva FRMB, Loss ES \& McConnell LL. Biochemical factors involved in the FSH action on amino acid transport in immature rat testes. Hormone and Metabolic Research 199224 276-279.

37 Means AR, Dedman JS, Tash JS, Tindall DS, Van Sicle M \& Welsh MJ. Regulation of the testis Sertoli cell by follicle stimulating hormone. Annual Reviews of Physiology 198042 59-70.

38 Marion S, Robert F, Crepieux P, Martinat N, Troispoux C, Guillou F et al. G-protein-coupled receptor kinases and beta arrestins are localized and attenuate cyclic $3^{\prime}, 5^{\prime}$-adenosine monophosphate response to follicle-stimulating hormone in rat primary Sertoli cells. Biology of Reproduction 200266 70-76.

39 Grasso P \& Reichert LE Jr. Follicle-stimulating hormone receptormediated uptake of ${ }^{45} \mathrm{Ca}^{2+}$ by proteoliposomes and cultured rat Sertoli cells: evidence for involvement of voltage-activated and voltage-independent calcium channels. Endocrinology 1989125 3029-3036.

40 Wassermann GF \& Loss ES. Effect of a calcium channel blocker, verapamil, on amino acid uptake stimulated by $\mathrm{FSH}$ in rat testes. Medical Science Research 198917 779-780.

41 Wassermann GF, Monti Bloch L, McConnell LL \& Grillo ML. FSHinduced rapid hyperpolarization followed by a $\mathrm{Ca}^{2+}$ channelmediated depolarization in rat Sertoli cells. Medical Science Research $1990 \mathbf{1 8} 175-176$.

42 Brown AM \& Birnbaumer L. Ionic channels and their regulation by G protein subunits. Annual Reviews of Physiology $1990 \mathbf{5 2}$ 197-213.

43 Wassermann GF, Monti Bloch L, Grillo ML, Silva FRMB, Loss ES \& McConnell LL. Electrophysiological changes of Sertoli cells produced by the acute administration of amino acid and FSH. Hormone and Metabolic Research 199224 326-328.

44 Leung PC \& Steele GL. Intracellular signaling in the gonads. Endocrine Reviews 199213 476-498.

45 Joffre M \& Roche A. Follicle-stimulating hormone induces hyperpolarization of immature rat Sertoli cells in monolayer culture. Journal of Physiology $1988 \mathbf{4 0 0} 481-499$.

46 Roche A \& Joffre M. Effect of uncoupling treatments on FSH-induced hyperpolarization of immature rat Sertoli cells from Sertoli cell-enriched cultures. Journal of Reproduction and Fertility $198985343-354$.

47 Lalevée N, Pluciennik F \& Joffre M. Voltage-dependent calcium current with properties of T-type current in Sertoli cells from immature rat testis in primary cultures. Biology of Reproduction 199756 680-687.

48 Lalevée N \& Joffre M. Inhibition by cAMP of calcium-activated chloride currents in cultured Sertoli cells from immature testis. Journal of Membrane Biology 1999169 167-174.

49 Christensen HN, Aspen AJ \& Rice EG. Metabolism in the rat of three amino acids lacking $\alpha$-hydrogen. Journal of Biological Chemistry $1956220287-294$.

50 Irusta $\mathrm{O} \&$ Wassermann GF. FSH action on the $\alpha$-aminoisobutyric acid transport in the pre-puberal rat testes. Acta Physiologica Latinoamericana 197222 276-278.

51 Silva FRMB \& Wassermann GF. Kinetics of FSH stimulation of methylaminoisobutyric acid uptake in Sertoli cell in culture from testes of 15 day-old rats. Medical Science Research 199927 $627-630$.

52 Irusta $\mathrm{O} \&$ Wassermann GF. Factors influencing the uptake of $\left[\alpha-{ }^{14} \mathrm{C}\right]$ aminoisobutyric acid by rat testes. Journal of Endocrinology $197460463-471$.

53 Cruz Curte A \& Wassermann GF. Identification of amino acid transport systems stimulated by FSH in rat testes. Journal of Endocrinology 1985106 291-294.

54 Perez-Sanches VH \& Wassermann GF. Amino acid transport in rat Sertoli cell enriched testes: studies on the mechanism of action of follicle-stimulating hormone. Brazilian Journal of Medical and Biological Research $19811411-17$.

55 Grasso P \& Reichert LE. Follicle-stimulating hormone receptormediated uptake of ${ }^{45} \mathrm{Ca}^{2+}$ by cultured rat Sertoli cells does not require activation of cholera toxin- or pertussis toxin-sensitive guanine nucleotide binding proteins or adenylate cyclase. Endocrinology 1990127 949-956.

56 Davare MA, Avdonin V, Hall DD, Peden EM, Burette A, Weinberg $\mathrm{RJ}$ et al. $\mathrm{B}_{2}$ adrenergic receptor signaling complex assembled with the $\mathrm{Ca}^{2+}$ channel $\mathrm{Ca}_{\mathrm{v}}$ 1.2. Science 2001293 98-101.

57 Vieira AV, Schneider WJ \& Vieira PM. Retinoids: transport, metabolism, and mechanism of action. Journal of Endocrinology $1995146201-207$

58 Porter SB, Ong DE, Chytil F \& Orgebin-Crist MC. Localization of cellular retinol-binding protein and cellular retinoic acid-binding protein in the rat testis and epididymis. Journal of Andrology 1985 6 197-212.

59 Blaner WS, Galdieri M \& Goodman DS. Distribution and levels of cellular retinol and cellular retinoic acid-binding protein in various types of rat testis cells. Biology of Reproduction 198736 $130-137$

60 Skinner MK. Cell-cell interactions in the testis. Endocrine Reviews $19911245-77$.

61 Canipari R \& Galdieri M. Retinoid modulation of plasminogen activator production in rat Sertoli cells. Biology of Reproduction $200063544-550$.

62 Dal-Pizzol F, Klamt F, Frota ML, Moraes LF, Moreira JC \& Benfato MS. Retinol supplementation induces DNA damage and modulates iron turnover in rat Sertoli cells. Free Radical Research $200033677-687$.

63 Klamt F, Dal-Pizzol F, Ribeiro NC, Bernard EA, Benfato MS \& Moreira JC. Retinol-induced elevation of ornithine decarboxylase activity in cultured rat Sertoli cells is attenuated by free radical scavenger and by iron chelator. Molecular and Cellular Biochemistry 2000208 71-76.

64 Wassermann GF, Silva FRMB, Grillo ML, Loss ES, Leite L \& von Ledebur EICF. Retinol stimulates amino acid transport in Sertoli cell by a $\mathrm{Ca}^{++}$related mechanism. Medical Science Research $199321437-438$.

65 Wassermann GF, Loss ES \& Wechsler SW. Retinol stimulates ${ }^{45} \mathrm{Ca}^{2+}$ uptake in Sertoli cells through a verapamil-sensitive voltage-dependent-channel. Medical Science Research 199523 633-634. 
66 Silva FRMB, Renck L \& Wassermann GF. Retinol stimulates amino acid transport in Sertoli cell by a mechanism unrelated to protein synthesis. Medical Science Research 199523 155-156.

67 Loss ES, Barreto KP, Leite L \& Wassermann GF. Comparative study of the actions of isoproterenol and retinol on amino acid accumulation, ${ }^{45} \mathrm{Ca}^{2+}$ uptake and membrane potential in Sertoli cells. Medical Science Research 199826 195-199.

68 De Boeck H \& Raphael Z. NMR study of the interaction of retinoid with phospholipid bilayers. Biochimica et Biophysica Acta 1988 $946244-252$.

69 Cope FO, Howard BD \& Boutwell RK. The in vitro characterization of the inhibition on mouse brain protein kinase- $\mathrm{C}$ by retinoids and their receptors. Experientia $1986 \mathbf{4 2} 1023-1027$.

70 Stillwell W, Ricketts M, Hudson H \& Nahmias S. Effect of retinol and retinoic acid on permeability, electrical resistance and phase transition of lipid bilayers. Biochimica et Biophysica Acta $1982668653-659$.

71 Manna PR, Tena-Sempere M \& Huhtaniemi IT. Molecular mechanisms of thyroid hormone-stimulated steroidogenesis in mouse Leydig tumor cells. Journal of Biological Chemistry 1999 274 5909-5918.

72 Sowikowska-Hilczer J, Marchlewska K, Oszukowska E, WalczakJêdrzejowska R \& Kula K. Spermatogenesis is a target for thyroid hormone. International Journal of Andrology 200023 (Suppl) $23-24$.

73 Jannini EA, Ulisse S \& D'Armiento M. Thyroid hormone and male gonadal function. Endocrine Reviews $199516443-459$.

74 Silva FRMB, Leite LD, Barreto KP, D’Agostini C \& Zamoner A. Effect of 3,5,3'-triiodo-L-thyronine on amino acid accumulation and membrane potential in Sertoli cells of the rat testis. Life Sciences $200169977-986$.

75 De Franca LR, Hess RA, Cooke PS \& Russel LD. Neonatal hypothyroidism causes delayed Sertoli cell maturation in rats treated with propylthiouracil evidence that the Sertoli cell controls testis growth. Anatomical Record $1995 \mathbf{2 4 2} 57-69$.

76 Lazzar MA. Thyroid hormone receptors: multiple forms, multiple possibilities. Endocrine Reviews $199314184-193$.

77 Jannini EA, Mitsuhashi T \& Nikodem VM. Developmental expression of mRNAs from a rat c-erbA genomic locus. Biochemistry and Biophysics Research Communication $1992 \mathbf{1 8 4}$ $739-745$.

78 Jannini EA, Carosa E, Rucci N, Screponi E \& D’Armiento M. Ontogeny and regulation of variant thyroid hormone receptor isoforms in developing rat testis. Journal of Endocrinological Investigation $199922843-848$.

79 Palmero S, De Marco P \& Fugassa E. Thyroid hormone receptor beta mRNA expression in Sertoli cells isolated from prepuberal testis. Journal of Molecular Endocrinology 199514 131-134.

80 Segal J, Hardiman J \& Ingbar SH. Stimulation of calcium-ATPase activity by $3,5,3^{\prime}$-tri-iodothyronine in rat thymocyte plasma membranes. Biochemical Journal $1989261749-754$.

81 Arambepola NK, Bunick D \& Cooke PS. Thyroid hormone and follicle-stimulating hormone regulate Mullerian-inhibiting substance messenger ribonucleic acid expression in cultured neonatal rat Sertoli cells. Endocrinology $19981394489-4495$.

82 Wrutniak C, Rochard P, Casas F, Fraysse A, Charrier J \& Cabello G. Physiological importance of the $\mathrm{T}_{3}$ mitochondrial pathway. Annals of the New York Academy of Sciences $1998 \mathbf{8 3 9} 93-100$.

83 Wrutniak-Cabello C, Casas F \& Cabello G. Thyroid hormone action in mitochondria. Journal of Molecular Endocrinology 2001 26 67-77.

84 Kobayashi M \& Horiuchi R. Action of 3,5,3'-tri-iodothyronine on the synthesis and secretion of major plasma proteins by a human hepatoblastoma cell line (Hep G2). Journal of Molecular Endocrinology $1995 \mathbf{1 4} 227-235$.
85 Laslett AL, Li LH, Jester WF Jr \& Orth JM. Thyroid hormone downregulates neural cell adhesion molecule expression and affects attachment of gonocytes in Sertoli cell-gonocyte cocultures. Endocrinology 2000141 1633-1641.

86 Goldfine ID, Simons CG \& Ingbar SH. Stimulation of the uptake of L-aminoisobutyric acid in rat thymocytes by L-triiodothyronine: a comparison with insulin and dibutyryl cyclic AMP. Endocrinology $197596802-809$.

87 Segal J \& Gordon A. The effects of actinomycin D, puromycin, cycloheximide and hydroxyurea on 3',5,3-triiodo-L-thyronine stimulated 2-deoxy-D-glucose uptake in chick embryo. Endocrinology $1975 \mathbf{1 0 1} 150-156$.

88 Segal J. In vivo effect of 3,5,3'-triiodothyronine on calcium uptake in several tissues in the rat: evidence for a physiological role for calcium as the first messenger for the prompt action of the thyroid hormone at the level of the plasma membrane. Endocrinology $199012717-24$

89 Norman AW, Song X, Zanello L, Bula C \& Okamura WH. Rapid and genomic biological responses are mediated by different shapes of the agonist steroid hormone, $1 \alpha, 25(\mathrm{OH})_{2}$ vitamin $\mathrm{D}_{3}$. Steroids $199964120-128$.

90 Bouillon R, Okamura WH \& Norman AW. Structure-function relationships in the vitamin D endocrine system. Endocrine Reviews 199516 200-257.

91 Haussler MR, Whitfield GK, Haussler CA, Hsieh JC, Thompson PD, Selznick SH et al. The nuclear vitamin D receptor: biological and molecular regulatory properties revealed. Journal of Bone and Mineral Research 199813 325-349.

92 Nemere I, Dormanen MC, Hammond MW, Okamura WH \& Norman AW. Identification of a specific binding protein for $1 \alpha, 25$-dihydroxyvitamin $\mathrm{D}_{3}$ in basal-lateral membranes of chick intestinal epithelium and relationship to transcaltachia. Journal of Biological Chemistry $199426923750-23756$.

93 Song X, Bishop JE, Okamura WH \& Norman AW. Stimulation of phosphorylation of mitogen-activated protein kinase by $1 \alpha, 25$ dihydroxyvitamin $\mathrm{D}_{3}$ in promyelocytic $\mathrm{NB}_{4}$ leukemia cells: a structure-function study. Endocrinology 1998139 457-465.

94 Habib FK, Maddy SQ \& Gelly KJ. Characteristic action of receptors for 1,25-dihydroxy vitamin $\mathrm{D}_{3}$ in the human testis. Journal of Steroid Biochemistry 199035 195-199.

95 Majumdar SS, Bartke A \& Stumpf WE. Vitamin D modulates the effects of follicle-stimulating hormone on Sertoli cell function and testicular growth in Siberian hamsters. Life Sciences 1994 55 1479-1486.

96 Gensure RC, Riggle PC, Antrobus SD \& Walters MR. Evidence for two classes of 1,25-dihydroxyvitamin $\mathrm{D}_{3}$ binding sites in classical vs. nonclassical target tissues. Biochemical and Biophysical Research Communications $1991 \mathbf{1 8 0} 867-873$.

97 Levy FO, Ree AH, Eikvar L, Govindan MV, Jahnsen T \& Hansson V. Glucocorticoid receptors and glucocorticoid effects in rat Sertoli cells. Endocrinology $1989 \mathbf{1 2 4} 430-436$.

98 Bernini GP, Brogi G, Argenino GF, Moretti A \& Salvetti A. Effects of long-term pravastatin treatment on spermatogenesis and on adrenal and testicular steroidogenesis in male hypercholesterolemic patients. Journal of Endocrinological Investigation $199821310-317$.

99 Russel LD \& Griswold MD. Spermatogonial transplantation - an update for the millennium. Molecular and Cellular Endocrinology $2000161117-120$.

Received 9 January 2002

Accepted 17 June 2002 